\title{
Potential antipsychotic action of the selective agonist of adenosine A1 receptors, 5'-Cl-5'-deoxy-ENBA, in amphetamine and MK-801 rat models
}

\author{
Krystyna Ossowska ${ }^{1} \mathbb{D} \cdot$ Barbara Kosmowska $^{1}$ (D) . Jadwiga Wardas ${ }^{1}$ (D)
}

Received: 15 November 2019 / Revised: 29 January 2020 / Accepted: 30 January 2020 / Published online: 26 March 2020

(c) The Author(s) 2020

\begin{abstract}
Background Disturbances of dopaminergic and glutamatergic transmissions have been suggested to be involved in the pathomechanisms underlying psychotic symptoms of schizophrenia. In line with this concept, hyperlocomotion induced by the dopaminomimetic amphetamine and the uncompetitive antagonist of NMDA receptors MK-801 (dizocilpine) in rodents is a generally established model for screening of new potential antipsychotic drugs. Since recent studies have indicated that receptors for adenosine may be targets for antipsychotic therapy, the aim of the present study was to investigate an influence of 5'-Cl-5'-deoxy-ENBA, a potent and selective adenosine $\mathrm{A}_{1}$ receptor agonist, on hyperlocomotion induced by amphetamine and MK-801.

Methods Locomotor activity was measured by Force Plate Actimeters where four force transducers located below the corners of the floor of the cage tracked the animal position on a Cartesian plane at each time point.

Results Hyperlocomotion induced by either amphetamine ( $1 \mathrm{mg} / \mathrm{kg} \mathrm{sc})$ or MK-801 (0.3 mg/kg ip) was inhibited by 5'-Cl-5'deoxy-ENBA ( $0.1 \mathrm{mg} / \mathrm{kg}$ ip). The effect of 5'-Cl-5'-deoxy-ENBA on the amphetamine- and MK-801-induced hyperlocomotion was antagonized by the selective antagonist of adenosine $\mathrm{A}_{1}$ receptor DPCPX at doses of 1 and $2 \mathrm{mg} / \mathrm{kg}$ ip, respectively. Conclusion The present study suggests that stimulation of adenosine $\mathrm{A}_{1}$ receptors may produce antipsychotic effects.
\end{abstract}

Keywords Adenosine A1 receptors · Amphetamine $\cdot$ MK-801 $\cdot$ Hyperlocomotion $\cdot$ Rat

\section{Introduction}

Schizophrenia is one of the most prevalent mental disorders. It is characterized by an appearance of the so-called "positive" (delusions, hallucinations, disorganized thinking) and "negative" (anhedonia, blunted affect, social withdrawal) symptoms, as well as affective disorders (depression or mania), and cognitive disturbances [1]. Although some progress has been made both in understanding of schizophrenia pathomechanisms and pharmacotherapy during recent decades, this disease is still incurable and its symptoms cannot be successfully controlled, yet.

Krystyna Ossowska

ossowska@if-pan.krakow.pl

1 Department of Neuropsychopharmacology, Maj Institute of Pharmacology, Polish Academy of Sciences, 31-343 Kraków, Poland
Two main hypotheses of schizophrenia pathomechanisms are currently accepted that claim that hyperfunction of dopaminergic and hypofunction of glutamatergic transmission underlie symptoms of this disease. In line with these concepts, amphetamines, which enhance the release of dopamine in the striatum, can exacerbate psychotic symptoms in schizophrenia, and produce positive symptoms in healthy subjects, which may develop into primary psychosis [1]. Both the amphetamine- and schizophrenia-induced positive symptoms are alleviated by neuroleptics whose therapeutic potency has been shown to correlate with blockade of $\mathrm{D}_{2}$ dopamine receptors [1]. On the other hand, phencyclidine (PCP), ketamine and other NMDA receptor antagonists are known to induce both positive and negative symptoms in healthy humans and may precipitate schizophrenia [1].

Based on the above-mentioned putative mechanisms underlying schizophrenia symptoms, a number of animal (rodent) models have been developed. Among them, hyperlocomotion induced by dopaminomimetics (amphetamines, cocaine) and uncompetitive NMDA receptor antagonists 
[PCP, ketamine, MK-801 (dizocilpine)], which is inhibited by neuroleptics, seems to model positive symptoms in schizophrenia patients. This behaviour is commonly used to screen of new potential antipsychotic agents [1].

Besides dopamine and glutamate, dysfunctions of other neurotransmitter/neuromodulator systems, e.g. adenosine have been suggested to play a role in the pathomechanisms of schizophrenia [1, 2].

Adenosine, a ubiquitous neuromodulatory nucleoside acts mainly, but not solely, through $\mathrm{G}$-protein-coupled $\mathrm{A}_{1}, \mathrm{~A}_{2 \mathrm{~A}}$, $\mathrm{A}_{2 \mathrm{~B}}$ and $\mathrm{A}_{3}$ receptors [3]. While inhibitory $\mathrm{A}_{1}$ and $\mathrm{A}_{3}$ adenosine receptors decrease adenylyl cyclase activity and cAMP level, facilitatory $\mathrm{A}_{2 \mathrm{~A}}$ and $\mathrm{A}_{2 \mathrm{~B}}$ receptors induce an opposite effect, i.e. activate adenylyl cyclase and increase cAMP level [3]. Adenosine receptors have been suggested to be potential therapeutic targets in several central nervous system disorders, e.g. epilepsy, brain ischemia, pain and inflammation, Parkinson's disease, essential tremor and others [3-5]. It has been hypothesized that dysregulation of adenosine neuromodulation may influence neurodevelopment in schizophrenia and contribute to appearance of its symptoms $[1,2]$. In line with this concept, both adenosine $A_{1}$ and $A_{2 A}$ receptor agonists have been found to inhibit hyperlocomotion or sensorimotor gating deficits induced by dopaminomimetics and/or NMDA receptor channel blockers in rodents [1, 2]. However, most animal studies have suggested sedative and amnestic effects of adenosine $\mathrm{A}_{1}$ agonists which can be disadvantageous in schizophrenia [1]. On the other hand, antagonists of $\mathrm{A}_{1}$ and $\mathrm{A}_{2 \mathrm{~A}}$ or a non-selective antagonist of adenosine receptors-caffeine-exhibited procognitive properties in memory impairment models [1]. In line with the latter findings, caffeine consumption is higher in schizophrenia patients probably because its use is associated with improved semantic fluency, cognitive speed, working and visual memory, and counteracting the medication-induced sedation [6]. Moreover, agonists of both these receptors induce also some peripheral effects which may limit their therapeutic use in brain diseases [7-9]. As far as adenosine $A_{1}$ receptor agonists are concerned, they induce negative dromo- and chronotropic effects in humans [8], slow down the heart rate, and decrease systolic blood pressure in animals $[7,10]$.

The aim of the present study was to examine potential antipsychotic properties of 5'-chloro-5'-deoxy-( \pm -ENBA (5'-Cl-5'-deoxy-ENBA), a potent and selective adenosine $\mathrm{A}_{1}$ receptor agonist, which binds to this receptor with nanomolar affinity $(\mathrm{Ki}=0.20-0.51 \mathrm{nM})$, which is 2500-20,000 times higher than that for $\mathrm{A}_{2 \mathrm{~A}}, \mathrm{~A}_{2 \mathrm{~B}}$ or $\mathrm{A}_{3}$ receptors, and penetrates the blood-brain barrier [11-14]. 5'-Cl-5'-deoxy-ENBA has already been found to reduce pain in the formalin test [11] or hyperalgesia and mechanical allodynia in the model of the neuropathic pain in mice [12]. This compound decreased locomotor activity and L-DOPA dyskinesia in mice and rats
$[5,13]$, and the harmaline-induced tremor (a model of essential tremor) in rats [5]. 5'-Cl-5'-deoxy-ENBA appeared better than other agonists of $\mathrm{A}_{1}$ adenosine receptors because its pharmacologically active doses were devoid of peripheral side effects, i.e. it did not affect heart rate or systolic blood pressure [12].

Our recent study has indicated that 5'-Cl-5'-deoxy-ENBA administered in rats decreased hyperactivity induced by harmaline [5]. Since harmaline is known to produce psychomotor agitation and hallucinations in humans [15], the above-mentioned effect of 5'-Cl-5'-deoxy-ENBA may suggest its antipsychotic properties. However, since the harmaline-induced hyperactivity in rodents is not an established model of psychoses, in the present study, we examined an antipsychotic potential of 5'-Cl-5'-deoxy-ENBA in two classical models, i.e. the amphetamine- and MK-801-induced increase in locomotor activity in rats.

\section{Materials and methods}

\section{Animals}

The experiments were carried out according to the EU Directive 2010/63/EU for animal experiments and were approved by the Local Ethics Committee at the Institute of Pharmacology (permission no: 1069/2013; annex 1069/2016; 234/2017). All efforts were made to minimize the number and suffering of animals used. Male Wistar Han rats (310-350 g) were kept under a 12/12-h light/dark cycle (the light on from 7 am to $7 \mathrm{pm}$ ) with free access to food and water. All experiments were carried out during the light period.

\section{Drugs}

D-Amphetamine hemisulfate salt (Sigma-Aldrich, Saint Louis, USA) and MK-801 (dizocilpine, Tocris Bioscience, Bristol, UK) were dissolved in physiological saline and administered at doses of $1 \mathrm{mg} / \mathrm{kg} \mathrm{sc}$, and $0.3 \mathrm{mg} / \mathrm{kg}$ ip, respectively. 5'-Chloro-5'-deoxy- $\mathrm{N}^{6}-( \pm)$-(endo-norborn2-yl)adenosine (5'-Cl-5'-deoxy-ENBA, Tocris Bioscience, Bristol, UK) was dissolved in $0.5 \%$ DMSO in physiological saline and administered at a dose of $0.1 \mathrm{mg} / \mathrm{kg}$ ip $30 \mathrm{~min}$ before amphetamine or MK-801. 8-Cyclopentyl-1,3-dipropylxanthine, a selective antagonist of adenosine $\mathrm{A}_{1}$ receptors (DPCPX, Tocris Bioscience, Bristol, UK) [16] was dissolved in $10 \%$ DMSO in physiological saline and administered at doses of 1 or $2 \mathrm{mg} / \mathrm{kg}$ ip $10 \mathrm{~min}$ before 5'-Cl-5'-deoxyENBA (40 min before amphetamine or MK-801). Physiological saline was used as the control for amphetamine and MK-801, 0.5\% DMSO for 5'-Cl-5'-deoxy-ENBA and 10\% DMSO for DPCPX (Fig. 1). 
Fig. 1 A description of groups of rats and time schedule of the experiment. ${ }^{\prime} \mathrm{Cl}-\mathrm{ENBA}$ 5'-Cl-5'-deoxy-ENBA, Amph amphetamine, $M K$ MK-801 (dizocilpine), SOLV solvent

A

EXPERIMENTAL GROUPS

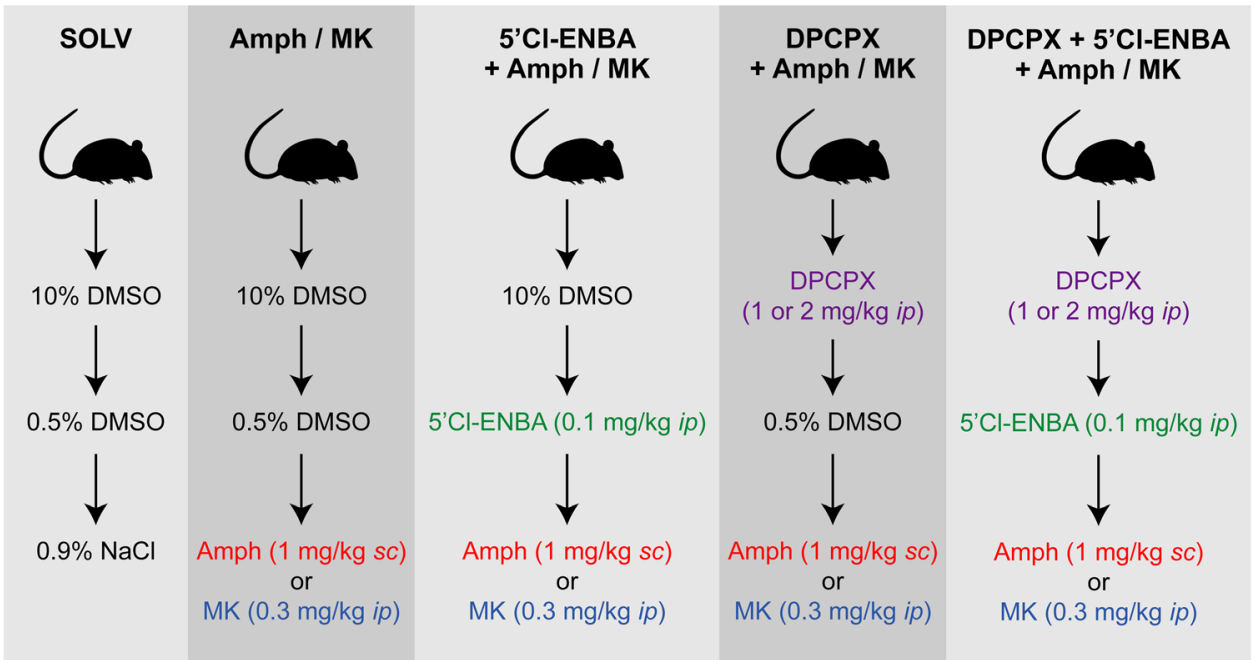

B

TIMELINE

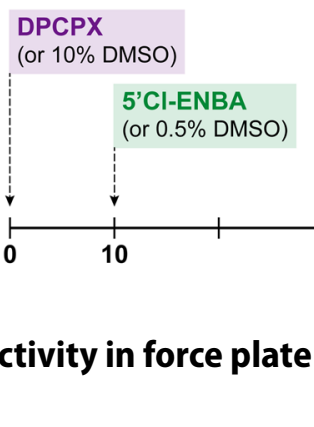

\section{Measurement of
actimeters (FPA)}

Immediately after amphetamine or MK-801 injections, rats were placed in the FPA. An animal was placed on a $40-\mathrm{cm} \times 40-\mathrm{cm}$ plate covered by a Plexiglas enclosure (33 cm high) and put into a ventilated sound-attenuating chamber. Four force transducers located below the corners of the plate tracked the animal position on a Cartesian plane at each time point (Fig. 2). Data were collected during time units of 20.48 s ("frames") with the sampling frequency of 50 points per second. The software calculated the total distance travelled in mm during three consecutive 60-frame series [three time periods of ca. $20 \mathrm{~min}$ each (20.48 min)] which was used as a measure of locomotor activity. Because vibration noise causes the measured position of the animal to fluctuate, this parameter could be artificially increased.

\section{Statistics}

Statistical analyses were carried out using the software Statistica v.13.3 (TIBCO Software Inc., Tulsa, OK, USA). ANOVA for repeated measures was used followed by LSD post hoc test for individual comparisons.

\section{Results}

\section{An influence of stimulation of adenosine A1 receptors on the amphetamine-induced increase in locomotor activity in rats}

Amphetamine administered at a dose of $1 \mathrm{mg} / \mathrm{kg} \mathrm{sc}$ increased the distance travelled by rats during the whole period (60 min) of recording (Figs. 2, 3). 5'-Cl-5'-deoxyENBA injected at a dose of $0.1 \mathrm{mg} / \mathrm{kg}$ ip inhibited the amphetamine-induced increase in locomotor activity by $\sim 40 \%$. A significant effect was observed between 20 and $60 \mathrm{~min}$ after amphetamine (50-90 min after 5'-Cl-5'deoxy-ENBA). DPCPX (1 mg/kg ip) reversed the 5'-Cl-5'deoxy-ENBA effect. However, DPCPX alone diminished the amphetamine-induced hyperactivity (20-60 min after amphetamine, 60-100 min after DPCPX) (Fig. 3).

\section{An influence of stimulation of adenosine A1 receptors on the MK-801-induced increase in locomotor activity in rats}

MK-801 injected at a dose of $0.3 \mathrm{mg} / \mathrm{kg}$ ip extended the distance travelled by rats (Figs. 2, 4). The significant effect was noted between 20 and 60 min after administration of this agent. 5'-Cl-5'-deoxy-ENBA (0.1 mg/kg ip) decreased 
SOLV
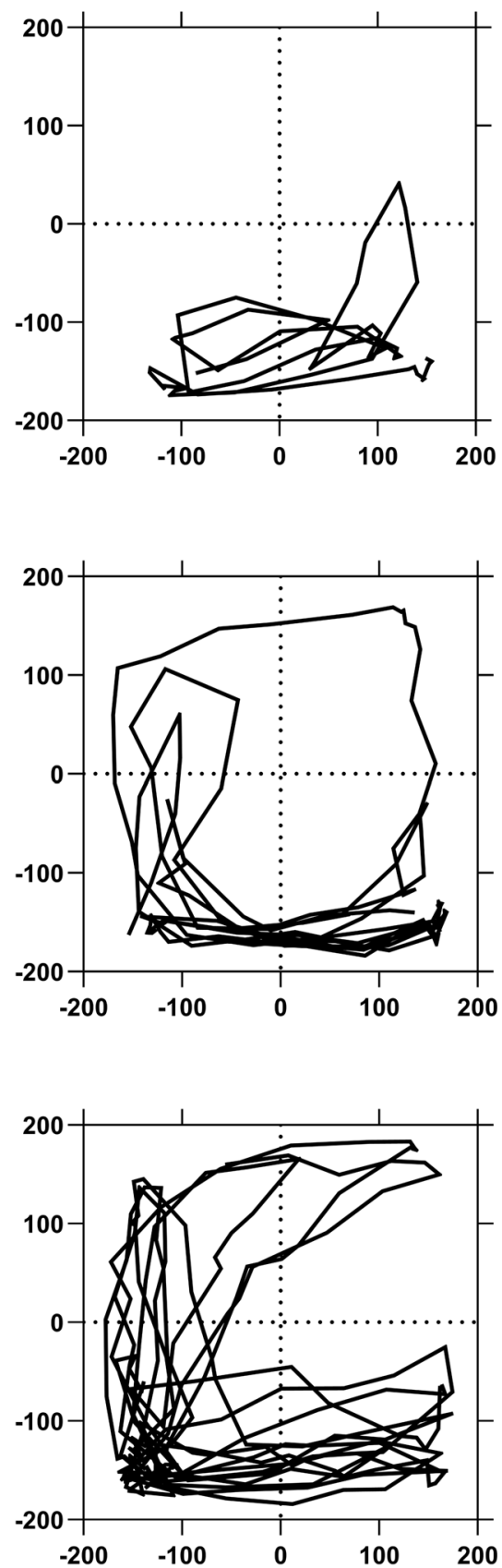

Amph
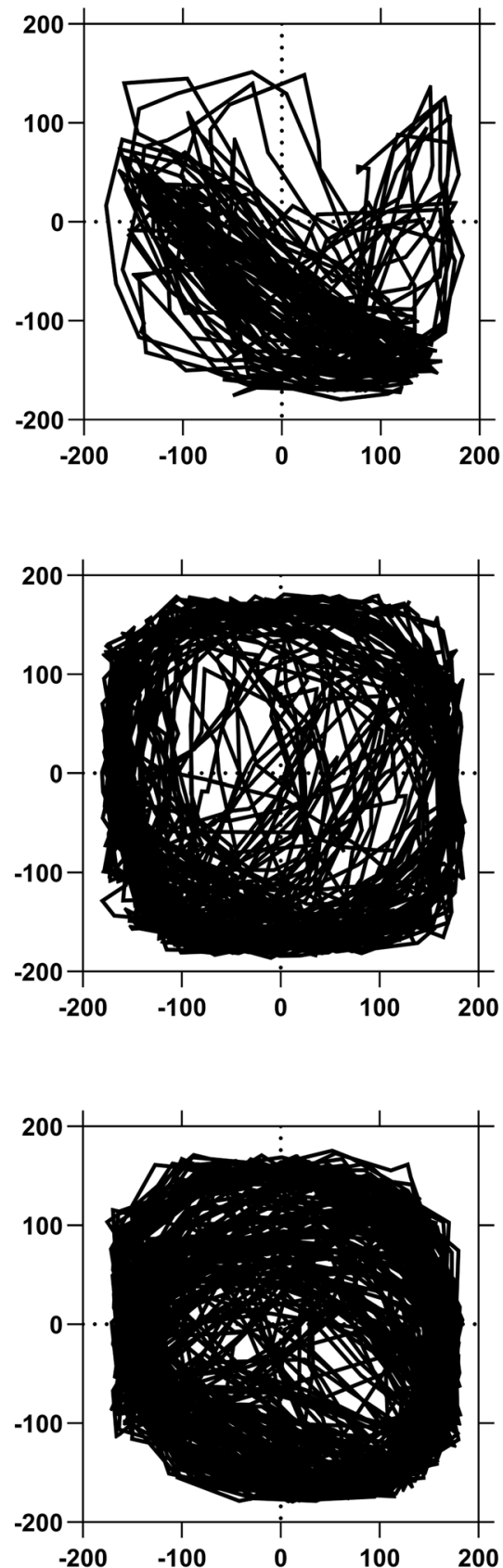

MK
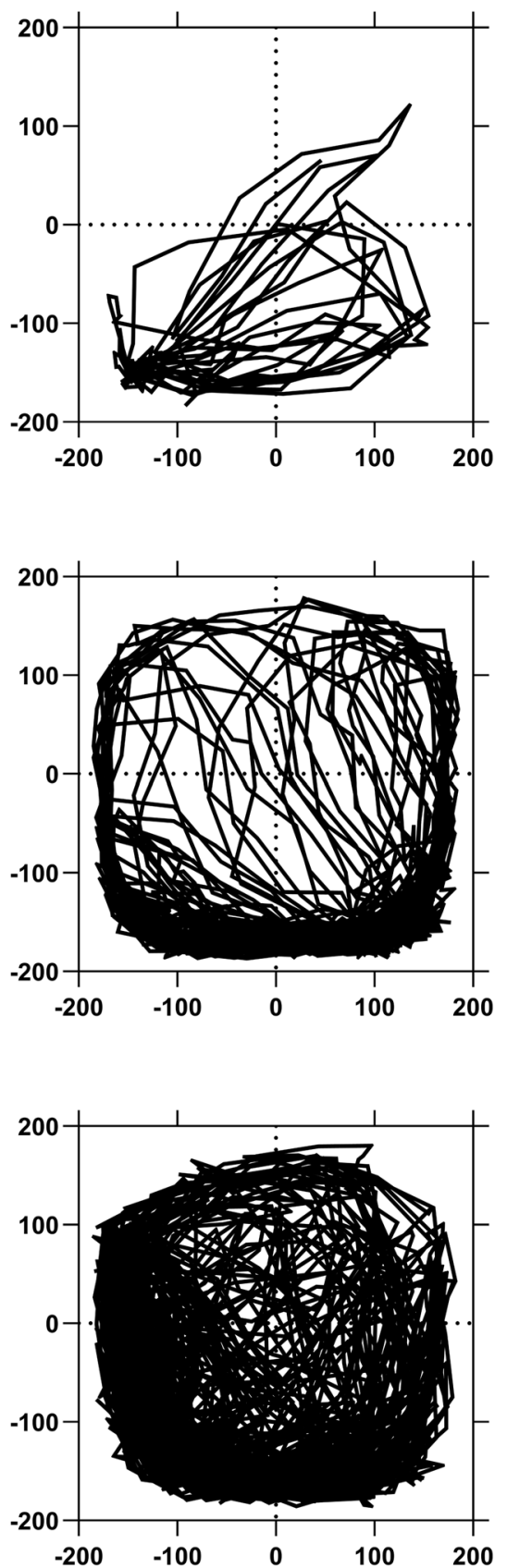

Fig. 2 Representative trajectories (averaged for $60 \mathrm{~min}$ ) of movements of animals treated with solvent (SOLV), amphetamine (Amph) and MK-801 (MK)

the MK-801-induced locomotor activation (20-60 min after MK-801, 50-90 min after 5'-Cl-5'-deoxy-ENBA) by $\sim 80 \%$ and this effect was inhibited by DPCPX given at a dose of 2 but not $1 \mathrm{mg} / \mathrm{kg}$ ip (Fig. 4a, b). DPCPX ( $1 \mathrm{mg} / \mathrm{kg}$ ip) alone diminished the MK-801-induced hyperlocomotion (20-60 min after MK-801, 60-100 min after DPCPX) (Fig. 4a). In contrast, the higher dose of this antagonist 


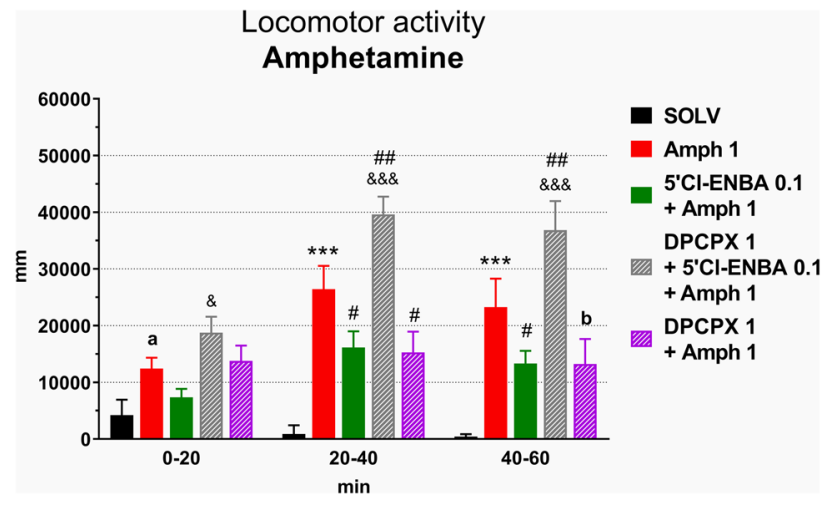

Fig. 3 An influence of stimulation of adenosine A1 receptors on the locomotor activity increased by amphetamine in rats. Ordinate: the total distance travelled in $\mathrm{mm}$, abscissa: the time after amphetamine injections. 5'Cl-ENBA $0.1, \quad 5$ '-Cl-5'-deoxy-ENBA at the dose of $0.1 \mathrm{mg} / \mathrm{kg}$; Amph 1, amphetamine at the dose $1 \mathrm{mg} /$ $\mathrm{kg}$; DPCPX 1, DPCPX at the dose of $1 \mathrm{mg} / \mathrm{kg}$. SOLV, solvent. The number of rats in groups: SOLV, $n=8$; Amph $1, n=15 ; 5^{\prime} \mathrm{Cl}-$ ENBA $0.1+$ Amph 1, $n=12$; DPCPX 1+5'Cl-ENBA $0.1+$ Amph 1, $n=9$; DPCPX 1+Amph 1, $n=7$. Statistics: ANOVA for repeated measures: treatment effect $(F[4,44]=10.6265, p=0.0000)$, time effect $(F[2,88]=18.5794, p=0.0000)$, treatment $\mathrm{x}$ time interaction $(F[8,88]=5.7804, p=0.0000)$. LSD post hoc test: $* * * p<0.001 \mathrm{vs}$. SOLV, ${ }^{a} p=0.094$ vs. SOLV, ${ }^{\#} p<0.05$ vs. Amph, ${ }^{\#} p<0.01$ vs. Amph, ${ }^{\mathrm{b}} p=0.058$ vs. Amph, ${ }^{\& \&} p<0.001$ vs. $5^{\prime} \mathrm{Cl}-\mathrm{ENBA}+\mathrm{Amph}$

( $2 \mathrm{mg} / \mathrm{kg}$ ip) did not influence the MK-801-induced hyperlocomotion (Fig. 4b).

\section{Discussion}

The present study shows that 5'-Cl-5'-deoxy-ENBA, a potent and highly selective adenosine $\mathrm{A}_{1}$ receptor agonist reduced the amphetamine- and MK-801-induced hyperlocomotion of rats, which was reversed by the antagonist of these receptors DPCPX. Since hyperlocomotion induced by the above compounds is generally accepted to be a model of positive psychotic symptoms in humans [1], the present data suggest that stimulation of adenosine $\mathrm{A}_{1}$ receptors may produce antipsychotic effects.

The above conclusion corroborates our initial thesis about a potential antipsychotic effect of 5'-Cl-5'-deoxy-ENBA, which was based on the inhibition of the harmaline-induced hyperactivity [5]. In our previous study, we found a dosedependent effect of 5'-Cl-5'-deoxy-ENBA $(0.01-0.5 \mathrm{mg} / \mathrm{kg})$ in the harmaline model [5]. On the basis of these experiments, we chose the dose of $0.1 \mathrm{mg} / \mathrm{kg}$ of this compound because of its marked effect on the harmaline-induced hyperactivity (ca. $40 \%$ reduction) and only slight inhibitory influence on spontaneous locomotor activity (ca. 20\%) [5]. Similarly, the inhibitory effect of this dose on the amphetamine- and, especially, MK-801-induced hyperlocomotion
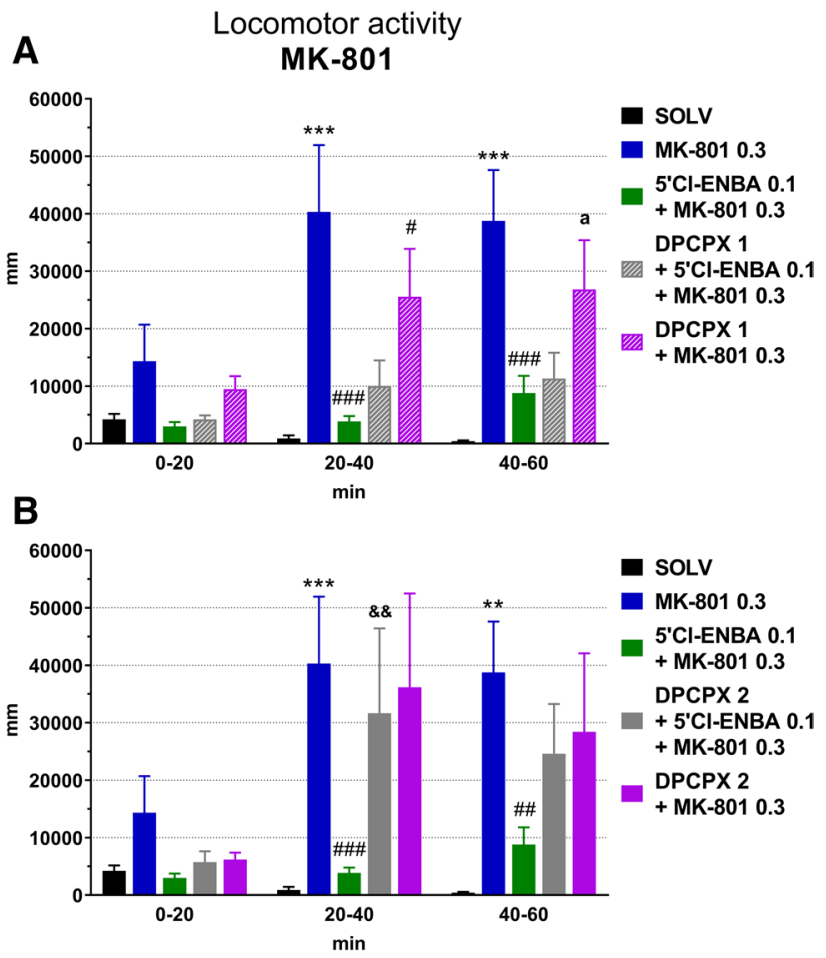

Fig. 4 An influence of stimulation of adenosine A1 receptors on the locomotor activity increased by MK-801 in rats. DPCPX 1, DPCPX at the dose of $1 \mathrm{mg} / \mathrm{kg}$; DPCPX 2, DPCPX at the dose of $2 \mathrm{mg} / \mathrm{kg}$; MK 0.3 , MK- 801 at the dose of $0.3 \mathrm{mg} / \mathrm{kg}$. The number of rats in groups: SOLV, $n=8$; MK-801 0.3, $n=10 ; 5^{\prime} \mathrm{Cl}$-ENBA $0.1+\mathrm{MK}$ $0.3, n=12$; DPCPX $1+5^{\prime}$ Cl-ENBA $0.1+$ MK $0.3, n=9$; DPCPX $2+5^{\prime} \mathrm{Cl}$-ENBA $0.1+\mathrm{MK} 0.3, n=11 ;$ DPCPX $1+\mathrm{MK} 0.3, n=8$; DPCPX $2+$ MK 0.3, $n=6$. Statistics for A: ANOVA for repeated measures: treatment effect $(F[4,39]=6.39543, p=0.0005)$, time effect $(F[2,78]=17.23720, p=0.0000)$, treatment $\times$ time interaction $(F[8,78]=4.74937, p=0.0000)$. LSD post hoc test: $* * * p<0.001 \mathrm{vs.}$ SOLV, ${ }^{\#} p<0.05$ vs. MK, ${ }^{\# \#} p<0.001$ vs. MK, ${ }^{a} p=0.098$ vs. MK. Statistics for B: ANOVA for repeated measures: treatment effect $(F[4,39]=3.47610, p=0.0160)$, time effect $(F[2,78]=13.8340$, $p=0.0000)$, treatment $\times$ time interaction $(F[8,78]=2.6085$, $p=0.0139)$. LSD post hoc test: $* * p<0.01$ vs. SOLV, $* * * p<0.001 \mathrm{vs.}$ SOLV, ${ }^{\#} p<0.01$ vs. MK, ${ }^{\# \#} p<0.001$ vs. MK, ${ }^{\&} \& p<0.01$ vs. $5^{\prime} \mathrm{Cl}-$ ENBA + MK. For further explanations, see Fig. 3

observed in the present study was clearly stronger than that on spontaneous motility [5], which allows us to suggest real antipsychotic potential of 5'-Cl-5'-deoxy-ENBA. Moreover, a slight decrease in spontaneous locomotor activity observed by us earlier [5] is not predictive of a strong sedative effect in humans.

Hypermotility induced by amphetamines is generally accepted to result from an increased release of dopamine in the ventral striatum, i.e. nucleus accumbens [17]. On the other hand, activation of adenosine $\mathrm{A}_{1}$ receptors by systemic or local administration of their agonists has repeatedly been described to reduce spontaneous dopamine release in the striatum and in the shell subregion of the nucleus accumbens in vivo and in vitro [18-20], as well as the 
methamphetamine-enhanced release of this neurotransmitter in the striatum [21]. Accordingly, antagonists of these receptors induced an opposite effect, i.e. they increased dopamine release in the striatum [19] and nucleus accumbens shell [22-25]. In rodents and humans, adenosine $A_{1}$ receptors (post- and pre-synaptic) are present in the striatum and nucleus accumbens [26, 27]. Some of them have been suggested to be localized on dopaminergic terminals in both these structures because their coding mRNA and/or protein expression was found in brain regions giving rise to mesolimbic and mesostriatal projections, i.e. in the ventral tegmental area $[26,27]$ and the substantia nigra pars compacta, respectively [27]. Moreover, an inhibitory effect of adenosine $A_{1}$ receptors on adenylyl cyclase activity in the striatum was lost in rats lesioned with 6-hydroxydopamine [28]. Although adenosine $A_{1}$ receptors located presynaptically on dopaminergic terminals may be involved in the decrease in exocytotic dopamine release shown by previous papers [18-20], their contribution to the inhibition of dopamine outflow [21] underlying hypermotility induced by amphetamines may be questioned because the latter is related to a reversal of dopamine transporter (DAT) function [29]. However, the stimulation of these receptors may inhibit dopamine synthesis in striatal varicosities and in this way it may lower its intraneuronal pool to be released by amphetamine. On the other hand, some lesion studies negated presynaptic localization of $A_{1}$ adenosine receptors on dopaminergic terminals in the striatum [30]. Therefore, another indirect mechanism modulating dopamine efflux seems to be more plausible.

It is well known that stimulation of adenosine $A_{1}$ receptors inhibits glutamate release in different brain structures, especially in the conditions when it is enhanced by, e.g. ischemia [31]. In line with this observation, an adenosine $A_{1}$ receptor agonist decreased, whereas an antagonist increased the release of this neurotransmitter in the nucleus accumbens shell and striatum [22, 23, 25, 32]. Both these structures receive projections from the cerebral cortex: from the sensorimotor/motor frontal cortex (striatum) [33] and association medial prefrontal cortex (nucleus accumbens) [34]. Since adenosine $A_{1}$ receptors are present on a majority of glutamatergic corticostriatal terminals where they form heteromers with $\mathrm{A}_{2 \mathrm{~A}}$ receptors [30,32], the above effects of the agonist and antagonist may result, at least partly, from their action on these presynaptic receptors.

A strong reciprocal dopaminergic-glutamatergic interaction exists in the nucleus accumbens. Accordingly, amphetamine has been found to increase the spontaneous release of glutamate in the nucleus accumbens [35], and vice versa dopamine release in this structure was enhanced by the stimulation of the cortico-accumbal projection and its terminals [34] via NMDA receptors [23], and the latter process involved dopamine reverse transport [29]. Therefore, it is supposed that the mechanism, which underlies the 5'-Cl-5'deoxy-ENBA-induced reversal of the amphetamine-induced hyperlocomotion, might involve initially a decrease in glutamatergic transmission, which secondarily results in the diminished DAT-dependent dopamine release.

The mechanisms responsible for hyperlocomotion induced by MK-801, although not completely understood, seem to be different from those of amphetamine. Although uncompetitive NMDA receptor antagonists increase dopamine release in the nucleus accumbens and medial prefrontal cortex, these biochemical effects have been found to be temporally dissociated from hyperlocomotion [36], which persisted after a lesion of monoaminergic pathways [37]. Instead, a strong relationship between glutamatergic neurotransmission in the medial prefrontal cortex and this behaviour has been suggested [38-41]. In line with this concept, uncompetitive NMDA receptor antagonists (including MK-801) increase glutamate release in this structure which via AMPA/kainate receptors excites pyramidal neurons, i.e. increases their metabolic activity, early gene expression, and firing [39-44].

Adenosine $\mathrm{A}_{1}$ receptors have been found to modulate neuronal activity and glutamatergic transmission in the cerebral cortex. Immunoreactivity of these receptors was detected in almost all pyramidal neurons of II-VI cortical layers, with the strongest signal in the layer V [27], and their stimulation inhibited the synaptic transmission in these cells [45]. Moreover, an adenosine $\mathrm{A}_{1}$ receptor agonist suppressed glutamate and aspartate release in the prefrontal cortex [46]. Therefore, it seems that the decrease in MK-801-induced hyperlocomotion by 5'-Cl-5'-deoxy-ENBA, observed in the present study, may be related to its inhibitory influence on the prefrontal cortex. It is worth mentioning here that the above-described behavioural 5'-Cl-5'-deoxy-ENBA effect on the MK-801 model was much stronger than that in the amphetamine model and, therefore, twice as high dose of DPCPX was necessary to antagonize it. Such strong effect of 5'-Cl-5'-deoxy-ENBA may be explained by much higher density of adenosine $A_{1}$ receptors in the cortex than in the basal ganglia (striatum, nucleus accumbens) in rats [26, 27].

Surprisingly, the present study shows that although DPCPX reversed the inhibitory effect of 5'-Cl-5'-deoxyENBA on the amphetamine- and MK-801-induced hyperlocomotion, this compound administered alone reduced both these behaviours. The mechanisms underlying this effect are unclear at present and may result from some unspecific properties of this antagonist. First, DPCPX has been reported to display both adenosine antagonist and adenosine agonist properties, the latter occurring at a site distal to cAMP, as shown in FRTL5 thyroid cell line [47]. Furthermore, while DPCPX is considered to be a potent and highly selective antagonist of $A_{1}$ receptors in sub- to low nanomolar concentrations $(\mathrm{Ki}=0.45-1.9 \mathrm{nM})$, it binds also to $\mathrm{A}_{2 \mathrm{~A}}$ receptors in 
concentrations ca. 50-700 times higher (100-330 nM) [16, 48]. In our experiments, we observed the inhibitory effect on hyperlocomotion of a dose of $1 \mathrm{mg} / \mathrm{kg}$, which is generally used to block adenosine $A_{1}$ receptors in vivo [49]. However, DPCPX administered in mice at a dose as low as $0.25 \mathrm{mg} /$ $\mathrm{kg}$ attains the level of ca. $340 \mathrm{nM}$ in the brain, which is high enough to bind additionally to $\mathrm{A}_{2 \mathrm{~A}}$ receptors [50]. In line with the putative dual action on $\mathrm{A}_{1}$ and $\mathrm{A}_{2 \mathrm{~A}}$ receptors, DPCPX already at the dose of $0.1 \mathrm{mg} / \mathrm{kg}$ induced the effect characteristic of an antagonist of $\mathrm{A}_{2 \mathrm{~A}}$ receptors, i.e. it reduced the ischemia-evoked aspartate and glutamate release in the cerebral cortex in rats [31]. In contrast to the cerebral cortex, the $\mathrm{A}_{2 \mathrm{~A}}$ component of DPCPX does not seem to influence striatal neurotransmission. Although antagonists of $\mathrm{A}_{2 \mathrm{~A}}$ receptors have been found to inhibit spontaneous or stimulated dopamine and glutamate release in the striatum and nucleus accumbens shell [24, 34, 51, 52], especially in conditions of concomitant blockade of $\mathrm{A}_{1}$ adenosine receptors [19], the intrastriatal administration of DPCPX did not reduce the methamphetamine-enhanced extracellular dopamine level [21]. Moreover, it seems controversial, whether $\mathrm{A}_{2 \mathrm{~A}}$ component of DPCPX may contribute to its effect on the amphetamine- and MK-801-induced hyperlocomotion. Although, knockout of $\mathrm{A}_{2 \mathrm{~A}}$ receptor in mice has been found by Moscoso-Castro and co-workers to decrease both spontaneous locomotor activity and that increased by amphetamine or MK-801 [53], other authors have shown either a lack of effect or an opposite effect of antagonists of these receptors $[1,2]$.

Stimulation of adenosine $A_{1}$ receptors has already been suggested to be related to the potential antipsychotic action [1]; however, agonists of these receptors slow down the heart rate and decrease systolic blood pressure in animals which may limit their use in humans $[7,10] .5^{\prime}$-Cl-5'-deoxy-ENBA seems to be devoid of systemic side effects of other $\mathrm{A}_{1}$ agonists because in centrally effective doses (up to $0.5 \mathrm{mg} / \mathrm{kg}$ ) in mice it neither induced cardiovascular effects nor disturbed motor coordination [12]. The reason of the lack of cardiovascular effect of this compound is unknown. It may stem from its ability to target mainly cells highly expressing adenosine $\mathrm{A}_{1}$ receptors, which was suggested by Luongo and co-workers [12]. In fact, density of these receptors in the heart is low in comparison to the brain [16]. However, another explanation may also be proposed. A recent study in knockout mice has shown that the activation of adenosine $\mathrm{A}_{3}$ receptors contributes to cardio-depressant effects of an adenosine analogue [54], and compounds expected to act selectively on adenosine $A_{1}$ receptors, at doses which strongly reduced heart rate $[7,54]$, influenced also adenosine $A_{3}$ receptors $[14,54] .5^{\prime}-\mathrm{Cl}-5^{\prime}$-deoxy-ENBA is the most selective agonist of adenosine $\mathrm{A}_{1}$ receptors currently known $[11,14]$ which might explain the lack of its peripheral actions [12]. This suggestion is supported by the recent finding that, at the dose used in the present study, it did not induce peripheral adenosine $\mathrm{A}_{3}$ receptor-dependent hypothermia in mice [14].

Summing up, the present study suggests potential antipsychotic action of 5'-Cl-5'-deoxy-ENBA, a potent and selective adenosine $A_{1}$ receptor agonist, which seems to be devoid of serious peripheral side effects.

Acknowledgements The study was supported by Statutory Funds of the Department of Neuropsychopharmacology, Maj Institute of Pharmacology, Polish Academy of Sciences, Kraków, Poland, and partly by the grant of the National Science Center, OPUS 6 (2013/11/B/ NZ4/04565). The authors wish to express their gratitude to Dr. Radosława Wróbel for providing language help.

Author contributions KO: conceptualization; roles/writing-original draft, funding acquisition, and supervision. BK: data curation, methodology, visualization, formal analysis and investigation. JW: conceptualization, funding acquisition, and writing—review and editing.

\section{Compliance with ethical standards}

Conflict of interest The authors declare that they do not have any conflict of interest.

Open Access This article is licensed under a Creative Commons Attribution 4.0 International License, which permits use, sharing, adaptation, distribution and reproduction in any medium or format, as long as you give appropriate credit to the original author(s) and the source, provide a link to the Creative Commons licence, and indicate if changes were made. The images or other third party material in this article are included in the article's Creative Commons licence, unless indicated otherwise in a credit line to the material. If material is not included in the article's Creative Commons licence and your intended use is not permitted by statutory regulation or exceeds the permitted use, you will need to obtain permission directly from the copyright holder. To view a copy of this licence, visit http://creativecommons.org/licenses/by/4.0/.

\section{References}

1. Boison D, Singer P, Shen H-Y, Feldon J, Yee BK. Adenosine hypothesis of schizophrenia-opportunities for pharmacotherapy. Neuropharmacology. 2012;62(3):1527-43. https://doi. org/10.1016/j.neuropharm.2011.01.048.

2. Wardas J. Potential role of adenosine A2A receptors in the treatment of schizophrenia. Front Biosci. 2008;13:4071-96. https:// doi.org/10.2741/2995.

3. Borea PA, Gessi S, Merighi S, Varani K. Adenosine as a multisignalling guardian angel in human diseases: when, where and how does it exert its protective effects? Trends Pharmacol Sci. 2016;37(6):419-33. https://doi.org/10.1016/j.tips.2016.02.006.

4. Morelli M, Di Paolo T, Wardas J, Calon F, Xiao D, Schwarzschild MA. Role of adenosine A2A receptors in parkinsonian motor impairment and L-DOPA-induced motor complications. Prog Neurobiol. 2007;83(5):293-309. https://doi.org/10.1016/j. pneurobio.2007.07.001.

5. Kosmowska B, Ossowska K, Głowacka U, Wardas J. Tremorolytic effect of 5'-chloro-5'-deoxy-( \pm -ENBA, a potent and selective adenosine A1 receptor agonist, evaluated in the harmalineinduced model in rats. CNS Neurosci Therap. 2017;23(5):438-46. https://doi.org/10.1111/cns.12692. 
6. Topyurek M, Tibbo P, Nunez C, Stephan-Otto C, Good K. Caffeine effects and schizophrenia: is there a need for more research? Schizophr Res. 2019;211:34-5. https://doi.org/10.1016/j.schre s.2019.07.026.

7. Schindler CW, Karcz-Kubicha M, Thorndike EB, Müller CE, Tella SR, Ferré S, et al. Role of central and peripheral adenosine receptors in the cardiovascular responses to intraperitoneal injections of adenosine A1 and A2A subtype receptor agonists. Br J Pharmacol. 2005;144(5):642-50. https://doi.org/10.1038/ sj.bjp.0706043.

8. Elzein E, Zablocki J. A1 adenosine receptor agonists and their potential therapeutic applications. Expert Opin Investig Drugs. 2008;17(12):1901-10. https://doi.org/10.1517/135437808024972 84.

9. Simola N, Wardas J (2015) Adenosine A2A receptors: localization and function. In: Morelli M, Simola N, Wardas J (eds) The adenosinergic system. The non-dopaminergic target in Parkinson's disease. Springer Int. Publ Switzerland. Curr Topics Neurotoxicity, 10: pp 1-25

10. Curros-Criado M, Herrero JF. The antinociceptive effects of the systemic adenosine A1 receptor agonist CPA in the absence and in the presence of spinal cord sensitization. Pharmacol Biochem Behav. 2005;82(4):721-6. https://doi.org/10.1016/j. pbb.2005.11.014.

11. Franchetti P, Cappellacci L, Vita P, Petrelli R, Lavecchia A, Kachler S, et al. $\mathrm{N}^{6}$-Cycloalkyl- and $\mathrm{N}^{6}$-bicycloalkyl-C5'(C2')-modified adenosine derivatives as high-affinity and selective agonists at the human A1 adenosine receptor with antinociceptive effects in mice. J Med Chem. 2009;52:2393-406. https://doi.org/10.1021/jm801456g.

12. Luongo L, Petrelli R, Gatta L, Giordano C, Guida F, Vita P, et al. 5'Chloro-5'-deoxy-( \pm -ENBA, a potent and selective adenosine $A_{1}$ receptor agonist, alleviates neuropathic pain in mice through functional glial and microglial changes without affecting motor or cardiovascular functions. Molecules. 2012;17(12):13712-26. https://doi.org/10.3390/molecules 1 71213712 .

13. Mango D, Bonito-Oliva A, Ledonne A, Cappellacci L, Petrelli $\mathrm{R}$, Nisticò $\mathrm{R}$, et al. Adenosine $\mathrm{A} 1$ receptor stimulation reduces D1 receptor-mediated GABAergic transmission from striatonigral terminals and attenuates L-DOPA-induced dyskinesia in dopamine-denervated mice. Exp Neurol. 2014;261:733-43. https ://doi.org/10.1016/j.expneurol.2014.08.022.

14. Carlin JL, Jain S, Gizewski E, Wan TC, Tosh DK, Xiao C, et al. Hypothermia in mouse is caused by adenosine $A_{1}$ and $A_{3}$ receptor agonists and AMP via three distinct mechanisms. Neuropharmacology. 2017;114:101-13. https://doi.org/10.1016/j.neuropharm .2016.11.026.

15. Frison G, Favretto D, Zancanaro F, Fazzin G, Ferrara SD. A case of $\beta$-carboline alkaloid intoxication following ingestion of Peganum harmala seed extract. Forensic Sci Int. 2008;179(2-3):e37e43. https://doi.org/10.1016/j.forsciint.2008.05.003.

16. Lohse MJ, Klotz K-N, Lindenborn-Fotinos J, Reddington M, Schwabe U, Olsson RA. 8-Cyclopentyl-1,2-dipropylcanthine (DPCPX) - a selective high affinity antagonist radioligand for A1 adenosine receptors. Naunyn-Schmiedeberg's Arch Pharmacol. 1987;336(2):204-10. https://doi.org/10.1007/bf00165806.

17. Heusner CL, Hnasko TS, Szczypka MS, Liu Y, During MJ, Palmiter RD. Viral restoration of dopamine to the nucleus accumbens is sufficient to induce a locomotor response to amphetamine. Brain Res. 2003;980(2):266-74. https://doi.org/10.1016/s0006 -8993(03)02986-x.

18. Ballarin M, Reiriz J, Ambrosio S, Mahy N. Effect of locally infused 2-chloroadenosine, an A1 receptor agonist, on spontaneous and evoked dopamine release in rat neostriatum.
Neurosci Lett. 1995;185(1):29-322. https://doi.org/10.1016/03043940(94)11217-7.

19. Okada M, Mizuno K, Kaneko S. Adenosine A1 and A2 receptors modulate extracellular dopamine levels in rat striatum. Neurosci Lett. 1996;212(1):53-6. https://doi.org/10.1016/03043940(96)12780-4.

20. Karcz-Kubicha M, Quarta D, Hope BT, Antoniou K, Müller $\mathrm{CE}$, Morales M, et al. Enabling role of adenosine A1 receptors in adenosine A2A receptor-mediated striatal expression of c-fos. Eur J Neurosci. 2003;18(2):296-302. https://doi.org/10.104 6/j.1460-9568.2003.02747.x.

21. Gołembiowska K, Żylewska A. Agonists of A1 and A2A adenosine receptors attenuate methamphetamine-induced overflow of dopamine in rat striatum. Brain Res. 1998;806(2):202-9. https:// doi.org/10.1016/s0006-8993(98)00743-4.

22. Solinas M, Ferré S, You Z-B, Karcz-Kubicha M, Popoli P, Goldberg SR. Caffeine induced dopamine and glutamate release in the shell of the nucleus accumbens. J Neurosci. 2002;22(15):6321-4. https://doi.org/10.1523/JNEUROSCI.2215-06321.2002.

23. Quarta D, Borycz J, Solinas M, Patkar K, Hockemeyer J, Ciruela F, et al. Adenosine receptor-mediated modulation of dopamine release in the nucleus accumbens depends on glutamate neurotransmission and $N$-methyl-D-aspartate receptor stimulation. J Neurochem. 2004;91(4):873-80. https://doi.org/ 10.1111/j.1471-4159.2004.02761.x.

24. Quarta D, Ferré S, Solinas M, You ZB, Hockemeyer J, Popoli $\mathrm{P}$, et al. Opposite modulatory roles for adenosine A1 and A2A receptors on glutamate and dopamine release in the shell of the nucleus accumbens Effects of chronic caffeine exposure. J Neurochem. 2004;88(5):1151-8. https://doi.org/10.104 6/j.1471-4159.2003.02245.x.

25. Borycz J, Pereira MF, Melani A, Rodrigues RJ, Köfalvi A, Panlilio L, et al. Differential glutamate-dependent and glutamate-independent adenosine A1 receptor-mediated modulation of dopamine release in different striatal compartments. J Neurochem. 2007;101(2):355-63. https://doi.org/10.111 1/j.1471-4159.2006.04386.x.

26. Mahan LC, McVittie LD, Smyk-Randall EM, Nakata H, Monsma FJ Jr, Gerfen CR, et al. Cloning and expression of an A1 adenosine receptor from rat brain. Mol Pharmacol. 1991;40(1):1-7.

27. Rivkees SA, Price SL, Zhou FC. Immunohistochemical detection of A1 adenosine receptors in rat brain with emphasis on localization in the hippocampal formation, cerebral cortex, cerebellum, and basal ganglia. Brain Res. 1995;677(2):193-203. https://doi. org/10.1016/0006-8993(95)00062-u.

28. Moser A, Liebetrau A, Cramer H. Adenosine receptor-coupled adenylate cyclase in the caudate nucleus of the rat brain. Neuropharmacology. 1991;30(7):769-73. https://doi.org/10.1016/00283908(91)90185-e.

29. Levier V. Dopamine release mediated by the dopamine transporter, facts and consequences. J Neurochem. 2011;118(4):47589. https://doi.org/10.1111/j.1471-4159.2011.07335.x.

30. Wojcik WJ, Neff NH. Differential location of adenosine A1 and A2 receptors in striatum. Neurosci Lett. 1983;41(1-2):55-60. https://doi.org/10.1016/0304-3940(83)90222-7.

31. Simpson RE, O'Regan MH, Perkins LM, Phillis JW. Excitatory transmitter amino acid release from the ischemic rat cerebral cortex: effects of adenosine receptor agonists and antagonists. J Neurochem. 1992;58(5):1683-90. https://doi. org/10.1111/j.1471-4159.1992.tb10041.x.

32. Ciruela F, Casadó V, Rodrigues RJ, Luján R, Burgueño J, Canals $\mathrm{M}$, et al. Presynaptic control of striatal glutamatergic neurotransmission by adenosine A1-A2A receptor heteromers. J 
Neurosci. 2006;26(7):2080-7. https://doi.org/10.1523/JNEUR OSCI.3574-05.2006.

33. Donoghue JP, Kitai ST. A collateral pathway to the neostriatum from corticofugal neurons of the rat sensory-motor cortex: an intracellular HRP study. J Comp Neurol. 1981;201(1):1-13. https ://doi.org/10.1002/cne.902010102.

34. Quiroz C, Orrú M, Rea W, Ciudad-Roberts A, Yepes G, Britt JP, et al. Local control of extracellular dopamine levels in the medial nucleus accumbens by a glutamatergic projection from the infralimbic cortex. J Neurosci. 2016;36(3):851-9. https://doi. org/10.1523/JNEUROSCI.2850-15.2016.

35. Reid MS, Hsu K Jr, Berger SP. Cocaine and amphetamine preferentially stimulate glutamate release in the limbic system: studies on the involvement of dopamine. Synapse. 1997;27(2):95105. https://doi.org/10.1002/(SICI)1098-2396(19971 0)27:2\%3c95:AID-SYN1\%3e3.0.CO;2-6.

36. Adams B, Moghaddam B. Corticolimbic dopamine neurotransmission is temporally dissociated from the cognitive and locomotor effects of phencyclidine. J Neurosci. 1998;18(14):5545-54. https ://doi.org/10.1523/JNEUROSCI.18-14-05545.

37. Carlsson M, Carlsson A. The NMDA antagonist MK- 801 causes marked locomotor stimulation in monoamine-depleted mice. J Neural Transm. 1989;75(3):221-6. https://doi.org/10.1007/bf012 58633.

38. Takahata R, Moghaddam B. Activation of glutamate neurotransmission in the prefrontal cortex sustains the motoric and dopaminergic effects of phencyclidine. Neuropsychopharmacology. 2003;28(6):1117-24. https://doi.org/10.1038/sj.npp.1300127.

39. Jodo E, Suzuki Y, Takeuchi S, Niwa S, Kayama Y. Different effects of phencyclidine and methamphetamine on firing activity of medial prefrontal cortex neurons in freely moving rats. Brain Res. 2003;962(1-2):226-31. https://doi.org/10.1016/s0006 -8993(02)03967-7.

40. Zuo DY, Zhang YH, Cao Y, Wu CF, Tanaka M, Wu YL. Effect of acute and chronic MK-801 administration on extracellular glutamate and ascorbic acid release in the prefrontal cortex of freely moving mice on line with open-field behavior. Life Sci. 2006;78(19):2172-8. https://doi.org/10.1016/j.lfs.2005.09.022.

41. López-Gil X, Babot Z, Amargós-Bosch M, Suñol C, Artigas F, Adell A. Clozapine and haloperidol differently suppress the MK801-increased glutamatergic and serotonergic transmission in the medial prefrontal cortex of the rat. Neuropsychopharmacology. 2007;32(10):2087-97. https://doi.org/10.1038/sj.npp.1301356.

42. Homayoun H, Moghaddam B. NMDA receptor hypofunction produces opposite effects on prefrontal cortex interneurons and pyramidal neurons. J Neurosci. 2007;27(43):11496-500. https:// doi.org/10.1523/JNEUROSCI.2213-07.2007.

43. Seiriki K, Kasai A, Kuwaki T, Nakazawa T, Yamaguchi S, Hashimoto H. Critical involvement of the orbitofrontal cortex in hyperlocomotion induced by NMDA receptor blockade in mice. Biochem Biophys Res Commun. 2016;480(4):558-63. https://doi. org/10.1016/j.bbrc.2016.10.089.

44. Lladó-Pelfort L, Celada P, Riga MS, Troyano-Rodríguez E, Santana N, Artigas F. Effects of hallucinogens on neuronal activity. Curr Top Behav Neurosci. 2018;36:75-105. https://doi. org/10.1007/7854_2017_473.

45. Brand A, Vissiennon Z, Eschke D, Nieber K. Adenosine A(1) and A(3) receptors mediate inhibition of synaptic transmission in rat cortical neurons. Neuropharmacology. 2001;40(1):85-95. https:// doi.org/10.1016/s0028-3908(00)00117-9.

46. Gołembiowska K, Dziubina A. Involvement of adenosine in the effect of antidepressants on glutamate and aspartate release in the rat prefrontal cortex. Naunyn Schmiedebergs Arch Pharmacol. 2001;363(6):663-70. https://doi.org/10.1007/s002100100421.

47. Frauman AG, Moses AC. The A1 adenosine receptor antagonist 1,3, dipropyl-8-cyclopentylxanthine (DPCPX) displays adenosine agonist properties in the FRTL5 thyroid cell line. Biochem Biophys Res Commun. 1989;159(1):355-62. https://doi. org/10.1016/0006-291x(89)92446-7.

48. Lu M, Wang B, Zhang C, Zhuang X, Yuan M, Wang H, et al. PQ-69, a novel and selective adenosine A1 receptor antagonist with inverse agonist activity. Purinergic Signal. 2014;10:619-29. https://doi.org/10.1007/s11302-014-9424-5.

49. Prediger RDS, Takahashi RN. Modulation of short-term social memory in rats by adenosine $\mathrm{A} 1$ and $\mathrm{A} 2 \mathrm{~A}$ receptors. Neurosci Lett. 2005;376:160-5. https://doi.org/10.1016/j.neule t.2004.11.049.

50. Baumgold J, Nikodijevic O, Jacobson KA. Penetration of adenosine antagonist into mouse brain as determined by ex vivo binding. Biochem Pharmacol. 1992;43:889-94. https://doi. org/10.1016/0006-2952(92)90257-j.

51. Corsi C, Melani A, Bianchi L, Pedata F. Striatal A2A adenosine receptor antagonism differentially modifies striatal glutamate outflow in vivo in young and aged rats. NeuroReport. 2000;11(11):2591-5. https://doi.org/10.1097/00001756-20000 8030-00048.

52. Pintor A, Quarta D, Pèzzola A, Reggio R, Popoli P. SCH 58261 (an adenosine $\mathrm{A}(2 \mathrm{~A})$ receptor antagonist) reduces, only at low doses, $\mathrm{K}(+)$-evoked glutamate release in the striatum. Eur $\mathbf{J}$ Pharmacol. 2001;421(3):177-80. https://doi.org/10.1016/s0014 -2999(01)01058-5.

53. Moscoso-Castro M, Gracia-Rubio I, Ciruela F, Valverde O. Genetic blockade of adenosine A2A receptors induces cognitive impairments and anatomical changes related to psychotic symptoms in mice. Eur Neuropsychopharmacol. 2016;26(7):1227-400. https://doi.org/10.1016/j.euroneuro.2016.04.003.

54. Yang JN, Wang Y, Garcia-Roves PM, Björnholm M, Fredholm $\mathrm{BB}$. Adenosine A(3) receptors regulate heart rate, motor activity and body temperature. Acta Physiol (Oxf). 2010;199(2):221-30. https://doi.org/10.1111/j.1748-1716.2010.02091.x.

Publisher's Note Springer Nature remains neutral with regard to jurisdictional claims in published maps and institutional affiliations. 